\title{
Communities' Satisfaction towards Housing Rehabilitation and Reconstruction Program after September 30, 2009, Earthquake in West Sumatra
}

\author{
Bambang Istijono, Taufika Ophiyandri, Diah Chairisna, and Ade Tadzkia \\ Centre for Disaster Studies, Andalas University, Kampus Unand Limau Manis, Padang 25163, Indonesia \\ Correspondence should be addressed to Bambang Istijono; bistijono1452@yahoo.co.id
}

Received 12 November 2015; Revised 31 January 2016; Accepted 16 February 2016

Academic Editor: Eric Lui

Copyright (C) 2016 Bambang Istijono et al. This is an open access article distributed under the Creative Commons Attribution License, which permits unrestricted use, distribution, and reproduction in any medium, provided the original work is properly cited.

\begin{abstract}
The government of Indonesia had provided the Rehabilitation and Reconstruction (RR) assistance to 194,636 houses for communities after September 30, 2009, earthquake in West Sumatra. The community-based development model was adopted in this housing program aid. This study aims to explore people's satisfaction towards the RR program and to identify the difference of satisfaction level between urban area and rural area. The research was carried out by conducting a questionnaire survey to 200 communities. The beneficiaries were invited to determine their satisfaction level based on 5 Likert scale from 1 as "not satisfied at all" to 5 as "absolutely satisfied." The satisfaction level was assessed by two factors, process of reconstruction and result of reconstruction. It was found that the level of communities' satisfaction is at average level. The satisfaction level of urban communities is 2.75 , while the satisfaction level of rural communities is slightly higher at 2.88. The satisfaction levels of urban and rural communities with the reconstruction process are at 2.63 and 2.75, respectively, while the satisfaction level with the results of the program is at 2.84 and at 2.95 , respectively. Communities' satisfaction with the result of reconstruction is higher than that with the process of reconstruction.
\end{abstract}

\section{Introduction}

The earthquake of 7.6 on the Richter scale that occurred on September 30, 2009, at 17:16 pm had devastated West Sumatra. It was reported that there were 1195 casualties, and the losses and damage were approximately Rp. 15.41 trillion. The earthquake has created instability in economy and destroyed office buildings, educational and medical facilities, worship buildings, markets, bridges, roads, and public houses. The total damage to the community houses included 249,833 housing units. They were assessed as follows: 114.797 units were severely damaged, 67,198 units were moderately damaged, and 67,838 units were slightly damaged [1].

Concerning the damaged houses in West Sumatra, the government took the policy of implementing a model of community-based approach. In Indonesia, this model had previously been applied in Aceh after the earthquake and tsunami in 2004 and in Yogyakarta and Central Java after the earthquake in 2006. In this context, the community or society plays an important role in the implementation of the RR to their houses.

The success of an RR postearthquake program is apparently determined by the success of the program in the housing sector. The reason is that, after the emergency phase has ended, then the earthquake victims are eager to return to their normal life. One of the ways to get back to their normal life is to take the first step in the form of providing the houses for them; it is one of the basic human needs. If the victims are still living in shelters or temporarily staying at their relatives' houses, it would be very difficult for them to get back to their normal life.

The RR in housing sector can be categorized as a construction project, in which the success is determined by the accomplishment of project objectives. The accomplishment can be identified by several points, they are as follows: (a) the project ends on time, (b) the planned budget is achieved, and (c) the quality of the building construction is based on the standard. Considering that the RR housing program gives 
TABLE 1: IRBI of West Sumatra.

\begin{tabular}{lccc}
\hline City/regency & Number & Risk level & National rank \\
\hline Padang & 119 & High & 10 \\
Padang Pariaman & 98 & High & 30 \\
Solok & 96 & High & 36 \\
Agam & 94 & High & 37 \\
Tanah Datar & 89 & High & 51 \\
Pesisir Selatan & 82 & High & 74 \\
Kota Padang Panjang & 77 & High & 105 \\
Pasaman & 76 & High & 113 \\
Lima Puluh Koto & 76 & High & 114 \\
Kepulauan Mentawai & 73 & High & 138 \\
Sijunjung & 72 & High & 143 \\
Pasaman Barat & 64 & High & 179 \\
Pariaman & 56 & High & 242 \\
Bukittinggi & 56 & High & 243 \\
Kota Solok & 52 & High & 270 \\
Kota Payakumbuh & 52 & High & 271 \\
Dharmasraya & 45 & High & 332 \\
Solok Selatan & 44 & High & 341 \\
Sawahlunto & 44 & High & 342 \\
\hline Refence [2] & & &
\end{tabular}

Reference [2].

a direct impact on the victims who got the beneficence, then the satisfaction factors of the beneficiaries need to be added as a parameter of the success of an RR program. Based on this phenomenon, this study aims to analyze the extent of the success rate in terms of people's satisfaction towards RR housing program after the earthquake of September 30, 2009, in West Sumatra.

In addition, research conducted by UNSYIAH and UNHabitat [3] RR Aceh postearthquake program indicates that there are differences in the level of satisfaction of urban communities compared to rural communities. This study also suggests to find out the extent of differences in the level of satisfaction of urban communities compared to rural communities in West Sumatra after the earthquake.

\section{Literature Review}

2.1. Index Disaster Risk West Sumatra. West Sumatra is one of the provinces that is very vulnerable to disasters. According to BNPB [2] in the list of Disaster Risk Index Indonesia (IRBI), the vulnerability of West Sumatra was ranked the sixth of all provinces in Indonesia belonging to high classification. Furthermore 19 regencies/cities in West Sumatra also take the high risk of being vulnerable to disaster as shown in Table 1. The types of disaster that often occur in West Sumatra are floods, earthquakes, tsunamis, fire settlements, drought, extreme weather, landslides, volcanoes, and sea abrasion. Among those disasters that could likely occur in West Sumatra, an earthquake is considered as the most deadly disaster which caused a lot of loss and damage. In the last 10 years, a deadly earthquake occurred in 2007 and 2009.
TABLE 2: The number of victims and damage after September 30, 2009, earthquake.

\begin{tabular}{lc}
\hline The number of victims and damage & Total \\
\hline Loss of lives & 1,195 people \\
Severely injured & 619 people \\
Moderately injured & 1.179 people \\
Missing & 2 people \\
Severely damaged houses & 114,797 units \\
Tolerably damaged houses & 67,198 units \\
Moderately damaged houses & 67,838 units \\
Damaged offices & 442 units \\
Damaged education facilities & 4,748 units \\
Damaged health center buildings & 153 units \\
Damaged worship buildings & 2,851 units \\
Damaged marketplace facilities & 58 units \\
Damaged bridges & 68 units \\
Reference [1].
\end{tabular}

2.2. The Impact of September 30, 2009, Earthquake. The earthquake that occurred in West Sumatra on September 30, 2009 , is a type of subduction earthquake in the Indian Ocean tectonic plate beneath the Pacific Plate Asia. The epicenter as shown in Figure 1 is located at the coordinates of 0.84 degrees southern latitude and 99.65 east longitudes, $57 \mathrm{~km}$ away from the coast of Pariaman, in the depth of $71 \mathrm{~km}$.

This earthquake caused damage in 12 cities/regencies in West Sumatra. The areas that had been heavily damaged included Padang, Pariaman, Padang Pariaman, and Agam. In detail, the impacts of the earthquake are shown in Tables 2 and 3. Table 2 shows the negative impact of the earthquake of September 30, 2009, while Table 3 shows the impact of particular damage in the housing sector based on the affected areas.

2.3. Community-Based Method. Jha et al. [5] stated that the reconstruction of community-based/community can be either financial or material aid that is channeled through community organizations actively getting involved in decision making and management development. Referring to the model of community involvement proposed by Davidson et al. [6] and Ophiyandri et al. [7], the postdisaster housing reconstruction program is qualified to be considered as community-based program, that is, where the community involvement is at a level in the form of collaboration or empowerment (Figure 2).

This community-based RR method has been applied to some of the affected countries, such as India, Sri Lanka, Turkey, and Indonesia. Many advantages are obtained by the implementation of community-based RR [8-10], such as giving a strong sense of attachment towards RR program from the victims, rebuilding social networks in communities, high accountability, reducing corruption, and making it possible to implement the program in accordance with the culture and local customs. However, the community-based model of RR also has a limitation, since a prereconstruction takes quite a long time compared to the contractors based methods 


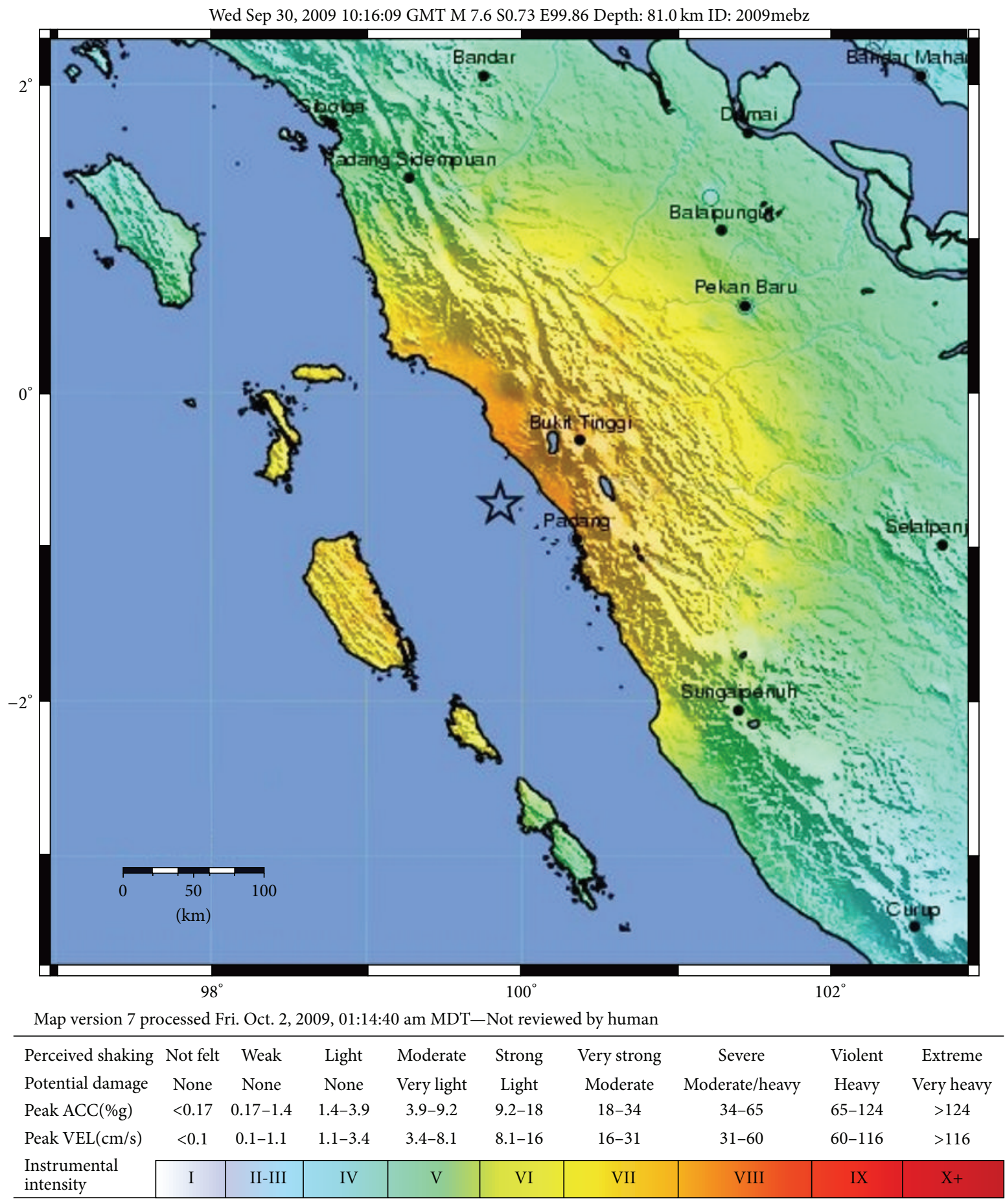

FIGURE 1: September 30, 2009, earthquake epicenter [4].

which lack understanding of how the community-based RR program should be implemented.

2.4. Implementation of $R R$ Housing in West Sumatra. Concerning the RR in West Sumatra, the government established a special agency called the Technical Assistance Team (TPT) which aims to strengthen local government in collecting data and planning, financing, facilitating and coordinating, supervising, monitoring, and evaluating of the RR. TPT works to create strategies and operational policies of the $\mathrm{RR}$. The implementation of the RR itself involves elements of the regional administration, from the province level to the lowest ones in the district/subdistrict of Nagari. Society in the area of RR implementation established community groups (Pokmas, Kelompok Masyarakat) consisting of 20-25 households. The Pokmas will be assisted by facilitators who 
TABLE 3: The number of damaged houses after September 30, 2009, earthquake in West Sumatra.

\begin{tabular}{|c|c|c|c|c|c|}
\hline \multirow{2}{*}{ Number } & \multirow{2}{*}{ Regencies/cities } & \multicolumn{3}{|c|}{ Level of damage } & \multirow{2}{*}{ Total } \\
\hline & & Heavily damaged & Moderately damaged & Lightly damaged & \\
\hline 1 & Padang & 33,597 & 35,816 & 37,615 & 107,028 \\
\hline 2 & Padang Pariaman Regency & 57,931 & 16,291 & 12,945 & 87,167 \\
\hline 3 & Pariaman & 6,685 & 4,115 & 2,605 & 13,028 \\
\hline 4 & Agam Regency & 11,796 & 3,797 & 4,353 & 19,946 \\
\hline 5 & Pesisir Selatan Regency & 1,156 & 3,596 & 5,510 & 10,262 \\
\hline 6 & Solok Regency & 145 & 243 & 357 & 745 \\
\hline 7 & Kepulauan Mentawai Regency & 3 & 0 & 136 & 139 \\
\hline 8 & Pasaman Barat Regency & 3,240 & 3,046 & 2,862 & 9,148 \\
\hline 9 & Pasaman Regency & 197 & 13 & 931 & 9,148 \\
\hline 10 & Padang Panjang & 17 & 164 & 413 & 594 \\
\hline 11 & Solok & 2 & 2 & 6 & 10 \\
\hline 12 & Tanah Datar Regency & 28 & 115 & 105 & 248 \\
\hline & Total & 114,797 & 67,198 & 67,838 & 249,833 \\
\hline
\end{tabular}

Reference [1].

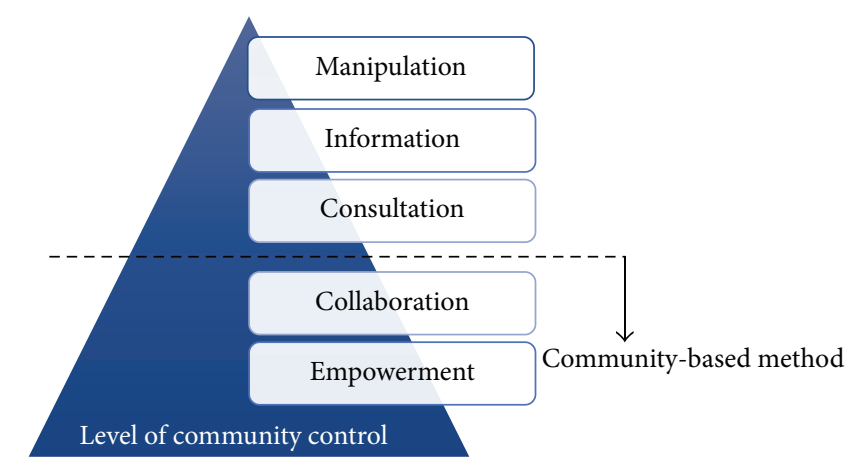

FIgURE 2: Minimum level of communities participation towards community-based method (after [6]).

work to assist community groups in both the administration and the technique of house construction.

In general, the RR housing was implemented at four phases, starting from 2009 to 2012 using financial source from the state budget. Due to the limited funds available, the housing assistance funds were the only stimulus. People whose houses were severely damaged received Rp. 15 million and those whose houses were moderately damaged received Rp. 10 million. The grants were distributed (transferred) directly to the bank account of community groups. Furthermore, the Pokmas distributed the funds to its members. Disbursement of funds was done at two phases, at phase $150 \%$ of the funds are set and at phase 2 another $50 \%$ of funds are disbursed after the reconstruction reaches at least $30 \%$ of funding phase I.

\section{Research Methodology}

This research was conducted using a survey method since it was considered to be the most appropriate method to answer the research questions being asked and to achieve the aim that had been targeted. Referring to Yin [11], the survey method was best used when a study has even led to the question "what," "how many," and "how much." This research referred to the questions as described by Yin. As it was not possible for researchers to conduct a survey on the entire population, a probability sampling method was applied. Type of sampling used was a multistage random sampling, with a probability area, and cluster random sampling as consideration. Selection of a multilevel sampling was done as follows: firstly, by selecting a survey region, they are the city and rural areas (district); secondly, the selection was made on the two areas most affected by the disaster, they are the city of Padang and Padang Pariaman district involving 100 samples in each area. In Padang area, the research was conducted in north Padang subdistrict and Koto Tangah subdistrict, while in Padang Pariaman the research was conducted in Sungai Sariak Region.

The questionnaire consisted of two main parts, the first one was the description of the respondent and the second one was the questions of satisfaction level. The respondents descriptions consisted of questions about gender, age, and occupation, including the amount of aid received. In addition, satisfaction level was measured using a 5-point Likert scale: 1 (not satisfied at all), 2 (not satisfied), 3 (satisfied), 4 (very satisfied), and 5 (absolutely satisfied). Satisfaction level on the process of the reconstruction has 14 indicators, while 
satisfaction on the result of reconstruction has 5 indicators. In addition, the respondents' satisfaction level in general towards the implementation of RR housing in West Sumatra was also asked.

Before the real questionnaire was distributed to the community, it should be tested to examine the responses and opinions from the public whether or not the need for changes to the contents of the questionnaire was needed and also to specify the methods to be used in the questionnaire distribution. The questionnaire was tested to 3 respondents. Based on results of the pilot questionnaire, there was no major revision to it, but only minor changing on rephrasing the questions and statements and no new parameter is added as well. In addition, it was found that respondents seemed to be careless and ignorant if the questionnaires were directly distributed to the respondents. As a result, the method of the survey was altered by implementing a structure interview by reading questions in the questionnaire directly to the respondents. Meanwhile, the researchers filled in the answers to the questionnaire. Questionnaires distribution was conducted from September 2014 to October 2014. The survey was generally carried out on Saturday or Sunday because the respondents were off work and they were expected to be in their house. The data which had been collected were then input in the computer into Microsoft Excel program for further statistical analysis.

\section{Results and Discussion}

4.1. Respondent Demographics. Table 4 shows the demographics of the respondents in both research locations. It appears that most of the respondents are female (77\%) and the predominant age is between 40 and 55 years old. The majority of education level of respondents in Padang is a high school (35\%), while in Padang Pariaman it is an elementary school (35\%). The most dominant type of job status is unemployed (including housewives).

Majority of respondents in Padang and Padang Pariaman said that the cost of rebuilding of their houses is around 2050 million. Furthermore, $66 \%$ of respondents in the city of Padang and $86 \%$ of the respondents in the district of Padang Pariaman claimed that the cost of the damage to their houses was more than Rp. 15 million. Meanwhile the number of respondents in Padang who received housing reconstruction funds of Rp. 10 million for their moderately damaged houses is 55 people and who received the funds of Rp. 15 million for their severely damaged houses is 45 people. In Padang Pariaman regency, the number of respondents who received housing reconstruction funds of Rp. 15 million for their moderately damaged houses is 31 people and who received the funds of Rp. 15 million for their severely damaged houses is 69 people. In general, $43 \%$ of respondents in the city of Padang acquired the funds after more than two years, while in the Padang Pariaman regency (40\%) they acquired the funds within 12 to 24 months after the earthquake.

4.2. Satisfaction Level. Figure 3 shows the average satisfaction level of respondents after September 30, 2009, earthquake reconstruction program in West Sumatra.
TABLE 4: Demographics of respondents based on the location of respondents.

\begin{tabular}{|c|c|c|}
\hline \multirow[b]{2}{*}{ Description } & \multicolumn{2}{|c|}{ Respondents' location } \\
\hline & Padang & $\begin{array}{c}\text { Padang } \\
\text { Pariaman }\end{array}$ \\
\hline \multicolumn{3}{|l|}{ (1) Gender } \\
\hline Male & 26 & 20 \\
\hline Female & 74 & 80 \\
\hline \multicolumn{3}{|l|}{ (2) Ages } \\
\hline 17-25 years old & 6 & 6 \\
\hline $25-40$ years old & 24 & 31 \\
\hline $40-55$ years old & 37 & 39 \\
\hline$>55$ years old & 33 & 24 \\
\hline \multicolumn{3}{|l|}{ (3) Levels of education } \\
\hline Uneducated & 6 & 12 \\
\hline Elementary school & 13 & 35 \\
\hline Junior high school & 17 & 11 \\
\hline Senior high school & 35 & 33 \\
\hline Diploma (colleges) & 13 & 1 \\
\hline Graduate (universities) & 13 & 8 \\
\hline Postgraduate (universities) & 3 & 0 \\
\hline \multicolumn{3}{|l|}{ (4) Jobs } \\
\hline Unemployed & 37 & 50 \\
\hline Farmer & 1 & 18 \\
\hline Civil servants & 12 & 4 \\
\hline Merchants/entrepreneurs & 20 & 19 \\
\hline Labors & 4 & 1 \\
\hline BUMN employees & 4 & 0 \\
\hline Fishermen & 6 & 0 \\
\hline Others & 19 & 8 \\
\hline \multicolumn{3}{|l|}{ (5) Monthly incomes levels } \\
\hline$<$ Rp. 1 million & 17 & 37 \\
\hline Rp. 1-2 million & 29 & 41 \\
\hline Rp. 2-3 million & 10 & 9 \\
\hline Rp. 3-5 million & 30 & 11 \\
\hline Rp. 5-10 million & 12 & 2 \\
\hline$>$ Rp. 10 million & 2 & 0 \\
\hline
\end{tabular}

(6) The estimated cost for the reconstruction of damaged houses

$<$ Rp. 5 million

Rp. 5-10 million

Rp. 10-15 million

Rp. 15-20 million

Rp. 20-50 million

$>$ Rp. 50 million

(7) The amount of fund received Rp. 10 million Rp. 15 million

(8) The period of funds received

$<6$ months

6 months -12 months

12 months -24 months

$>24$ months

\begin{tabular}{cc}
3 & 1 \\
22 & 4 \\
9 & 9 \\
6 & 22 \\
39 & 40 \\
21 & 24 \\
& \\
55 & 31 \\
45 & 69 \\
& \\
13 & 5 \\
22 & 23 \\
22 & 40 \\
43 & 31 \\
\hline
\end{tabular}

4.3. Satisfaction Levels in Padang. In general, it appears that the level of people's satisfaction with the RR housing program 


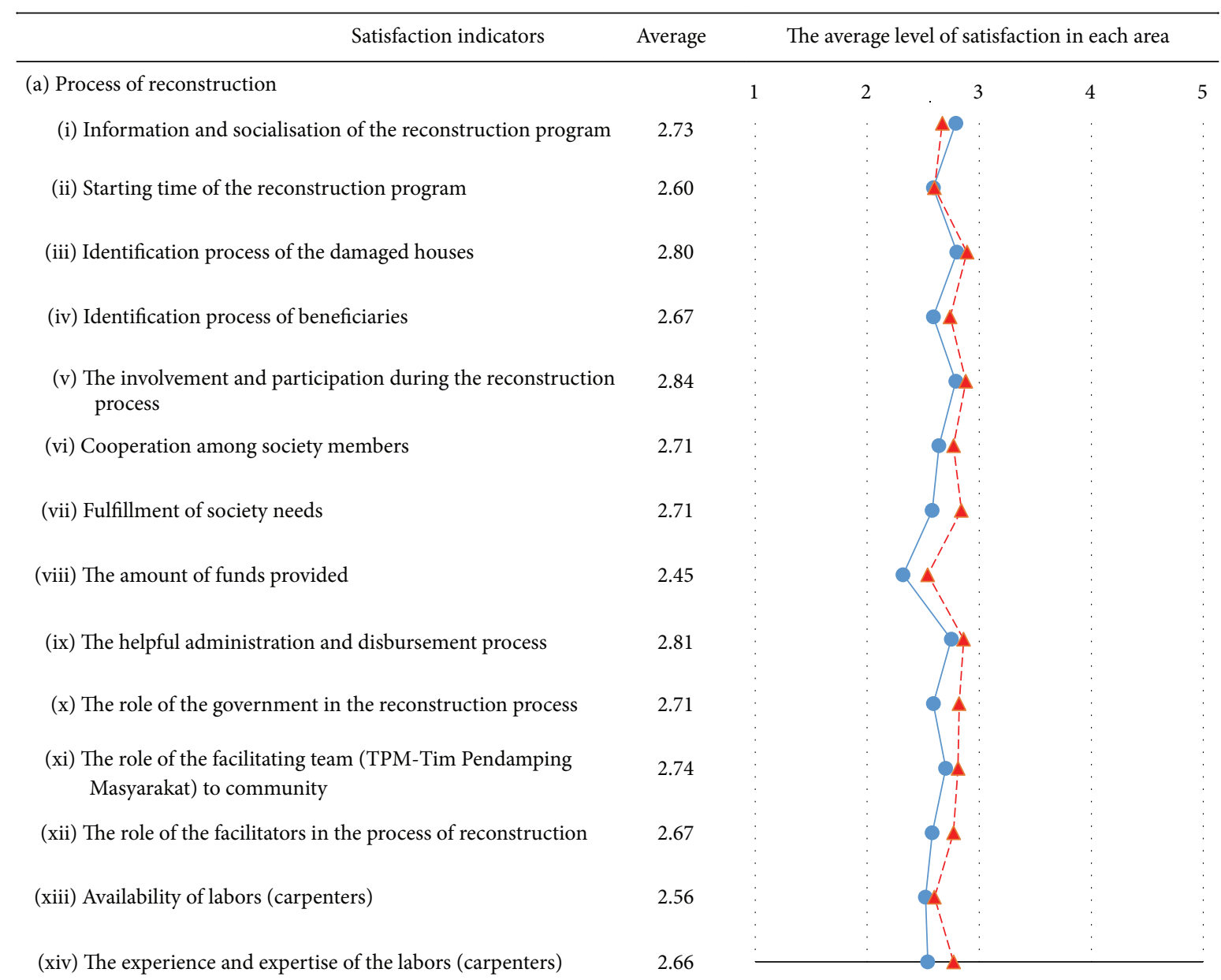

(b) Results of reconstruction

(i) The houses become more resistant to earthquakes

2.97

(ii) The houses become more comfortable

(iii) The quality of the houses is better houses

(iv) The houses have been as the beneficiaries want them to be

(v) The fulfillment of the government's promise

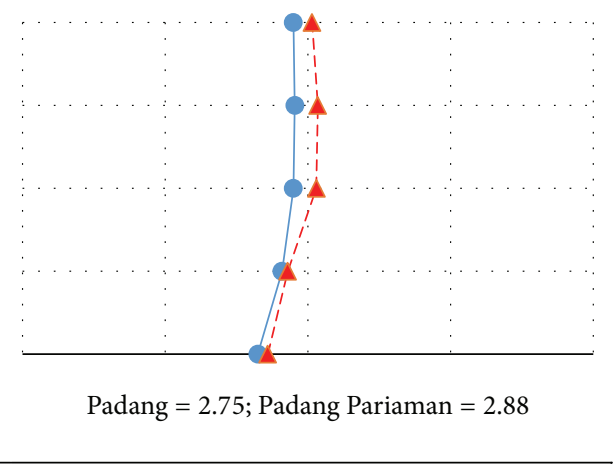

- Padang

- - Padang Pariaman

FIGURE 3: Average satisfaction level from society towards the reconstruction program.

in Padang is average. The indicating number of either the satisfaction or the reconstruction process to the results of the reconstruction is lower than 3 . The average satisfaction level of the Padang people's with the reconstruction process is 2.63. The highest level of satisfaction in this group reaches the indicator of the satisfaction with the damage assessment of their houses (2.80), including the indicator of satisfaction with the delivery of information and dissemination of the RR program to the beneficiaries and the indicator of the involvement/participation in the reconstruction (around 2.79). Meanwhile, the lowest level of satisfaction indicated the indicator of the amount of grants provided by the government 
(2.32) and the availability of labors (2.52). This condition could be understood because the maximum amount of funds given by the government was lower than the average requirement spent by RR society. As a result, people used their own private funds or chose to renovate only some parts of their houses that were urgently needed to renovate.

The indicator level of satisfaction with the reconstruction was slightly better than that of satisfaction with the reconstruction process. Meanwhile, the average level of satisfaction with the reconstruction quality is 2.84 . The highest satisfaction level can be identified by realizing people's comfort after having their newly renovated houses and including the feeling of confidence that their houses are more resistant to earthquakes. While the lowest level of satisfaction as the indicator of people's trust towards the government's promises was at 2.65. In general, people's satisfaction with the RR program in Padang was 2.75.

4.4. Satisfaction Levels in Padang Pariaman. In general, the average level of people's satisfaction with the communitybased reconstruction program in Padang Pariaman was to 2.88. It shared almost the same number as it was in Padang, which was 2.75 . So, it was lower than the level of satisfaction on the results of RR housing program, which was 2.95 .

The lowest satisfaction level is the indicator of the satisfaction with the amount of the government's funds given to the disaster victims (2.54). Meanwhile, the highest satisfaction level is the indicator of the people's satisfaction with the damage assessment to their houses (2.89).

Three of the five indicators of satisfaction with the result of the reconstruction were slightly better than average. These indicators were related to the perception of the beneficiaries who felt more comfortable in their houses (3.07), the houses' design looked better (3.06), and felt their new houses are more earthquake resistant (3.03). So, it indicates that the community members had internalized the principle of "building back better."

4.5. Cross-Case Analysis. The result of analysis of the satisfaction level of people in Padang and Padang Pariaman district shows that people in Padang Pariaman district (villages) are more satisfied with the program than those of Padang. As seen in Figure 3, from a total of 19 indicators of satisfaction, only one indicator of urban society is in the higher level than that of the rural communities, that is, an indicator of the availability of information and dissemination of the RR housing program. This phenomenon shows that people who live in cities have an access to information easier than the villagers. Furthermore, it should be the government's attention to equitable access of information to all levels of society. These results are in line with the results of the research carried out by UNSYIAH and UN-Habitat [3] related to the posttsunami in Aceh. In general, people's satisfaction level in Padang Pariaman is higher than those of Padang. In addition, the satisfaction level with the reconstruction process and the results of the reconstruction are higher too.

In general, based on the analysis of 200 respondents, it is noted that the people's satisfaction level was 2.82. Assessment of the satisfaction level with the process of reconstruction was
2.69 , while the assessment of result of the reconstruction was 2.90. This phenomenon could be a recommendation for the government not to focus only on the outcome of a program, but the process of reconstruction needs more attention and has to be handled carefully. In the RR housing communitybased program, the reconstruction process also plays an important role. The reason is that there are many benefits that can be obtained by conducting the community-based program, such as creating the unity among the community.

Both areas show that the lowest levels of satisfaction are in the indicator of the amount of the funds received. This indicator may appear due to more funds spent by the beneficiaries to reconstruct their house than the funds provided by the government. As suggested by Ophiyandri et al. [12], the availability of fund is one of the critical success factors of community-based postdisaster housing reconstruction project. In addition, it was worsened by the rise of building material prices. Material availability and prices should be controlled by the government. Fallahi [13] found that construction material aid contributed significantly to the success of Bam's reconstruction in Iran. Moreover, the labor wage became higher due to the high demand for labors, especially in disaster areas. Therefore, the government needs to rethink the best way to provide a financial assistance to the community. Giving insurance, opening an account for handling a disaster, and taking control to the rise of labor wages and building materials prices may become one of the solutions.

The differences in satisfaction levels between rural and urban communities may be related to the level of education, occupation, and the income of respondents. For example, in the case of income/salary, in Padang Pariaman, $78 \%$ of respondents had an income less than Rp. 2 million, while in the city of Padang only $46 \%$ respondents had an income less than Rp. 2 million. Logically, the lower income people would be more satisfied than people who earn higher if the amount of funds given is the same. Based on the correlation of the two phenomena, it is suggested to the future researchers to conduct the inferential statistical analysis.

\section{Conclusion}

The result of the research shows that the satisfaction level of communities in West Sumatra with the RR housing program is average, that is, 2.82 . If it is compared to the indicators of the reconstruction process and the results of the reconstruction, the satisfaction level with the results of the reconstruction is higher than that of the reconstruction process. The value of the reconstruction process is 2.69 and the value of the results of reconstruction is 2.90 .

In addition, based on the results obtained from the beneficiaries' satisfaction level in Padang and Padang Pariaman, it can be concluded that the satisfaction level of rural communities is higher than the satisfaction level of the urban communities. The satisfaction level of rural communities with the RR housing program is 2.88 , while the urban community is 2.75 . In more detail, the satisfaction level of urban and rural communities with the process of the RR housing program is 2.63 and 2.75 , while the satisfaction levels 
with the result of the RR housing program are 2.84 and 2.95 .

The lowest level of community satisfaction is on amount of funding provided by government to carry out reconstruction. This urges government to change the method for financial assistance to a more innovative way, such as by providing an earthquake insurance or creating a special account for each family to overcome disaster impact. Moreover, since the satisfaction value of "the process of reconstruction" is lower than "the result of reconstruction," government has to pay much attention on activities carried out in the former than the later. Especially in the communitybased reconstruction project, many of crucial activities are taken place in preconstruction stage.

\section{Competing Interests}

The authors declare that they have no competing interests.

\section{References}

[1] S. Pranoto, S. Sentosa, R. B. K. P. Kayo et al., Lesson Learned, Pembelajaran Rehab Rekon Pasca Gempa di Sumatera Barat 30 September 2009, Building Back Better, TPT RR, Padang, Indonesia, 2011.

[2] BNPB, Index Rawan Bencana Indonesia, BNPB, 2011.

[3] Universitas Syiah Kuala and UN-HABITAT, Post Tsunami Settlement Recovery Monitoring in Aceh, UNSYIAH-UNHABITAT, Banda Aceh, Indonesia, 2006.

[4] USGS, 2009, http://earthquake.usgs.gov/earthquakes/shakemap/ global/shake/2009 mebz/.

[5] A. K. Jha, J. D. Barenstein, P. M. Phelps, D. Pittet, and S. Sena, Safer Homes, Stronger Communities: A Handbook for Reconstructing after Natural Disasters, The World Bank, Washington, DC, USA, 2010.

[6] C. H. Davidson, C. Johnson, G. Lizarralde, N. Dikmen, and A. Sliwinski, "Truths and myths about community participation in post-disaster housing projects," Habitat International, vol. 31, no. 1, pp. 100-115, 2007.

[7] T. Ophiyandri, D. Amaratunga, and C. Pathirage, "Community based post disaster housing reconstruction: indonesian perspective," in Proceedings of the CIB World Congress, P. Barrett, D. Amaratunga, R. Haigh, K. Keraminiyage, and C. Pathirage, Eds., Salford Quays, UK, May 2010.

[8] H. Arslan and A. Unlu, "The evaluation of community participation in housing reconstruction projects after Duzce earthquake," in Proceedings of the International Conference and Student Competition on Post-Disaster Reconstruction, "Meeting Stakeholder Interests", Florence, Italy, May 2006, http://www .grif.umontreal.ca/pages/ARSLAN_\%20Hakan.pdf\#.

[9] J. D. Barenstein, "From Gujarat to Tamil Nadu: Owner-driven vs. contractor-driven housing reconstruction in India," 2008, http://humanitarianlibrary.org/resource/gujarat-tamil-naduowner-driven-vs-contractor-driven-housing-reconstructionindia- 0 .

[10] P. M. Lawther, "Community involvement in post disaster reconstruction-case study of the British red cross Maldives recovery program," International Journal of Strategic Property Management, vol. 13, no. 2, pp. 153-169, 2009.

[11] R. K. Yin, Case Study Research: Design and Methods, Sage, London, UK, 4th edition, 2009.
[12] T. Ophiyandri, D. Amaratunga, C. Pathirage, and K. Keraminiyage, "Critical success factors for community-based post-disaster housing reconstruction projects in the pre-construction stage in Indonesia," International Journal of Disaster Resilience in the Built Environment, vol. 4, no. 2, pp. 236-249, 2013.

[13] A. Fallahi, "Lessons learned from the housing reconstruction following the Bam earthquake in Iran," The Australian Journal of Emergency Management, vol. 22, no. 1, pp. 26-35, 2007. 


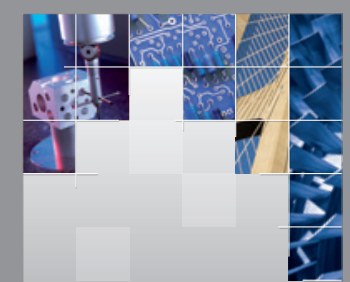

\section{Enfincering}
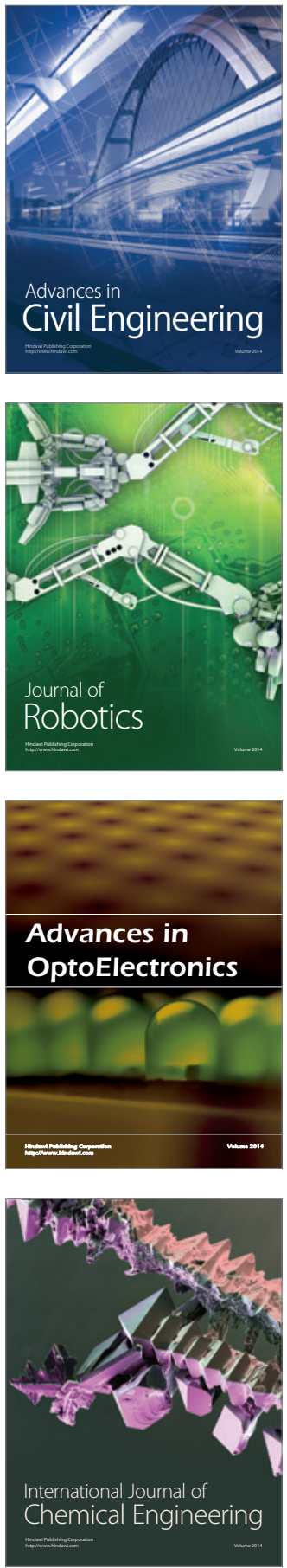

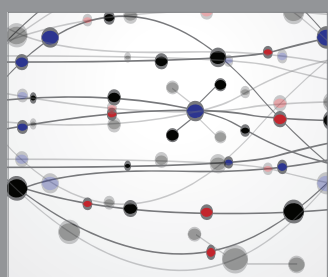

The Scientific World Journal

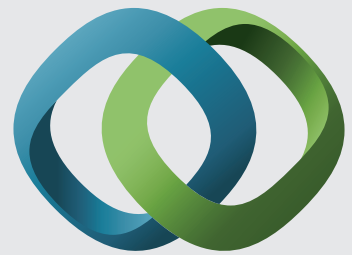

\section{Hindawi}

Submit your manuscripts at

http://www.hindawi.com
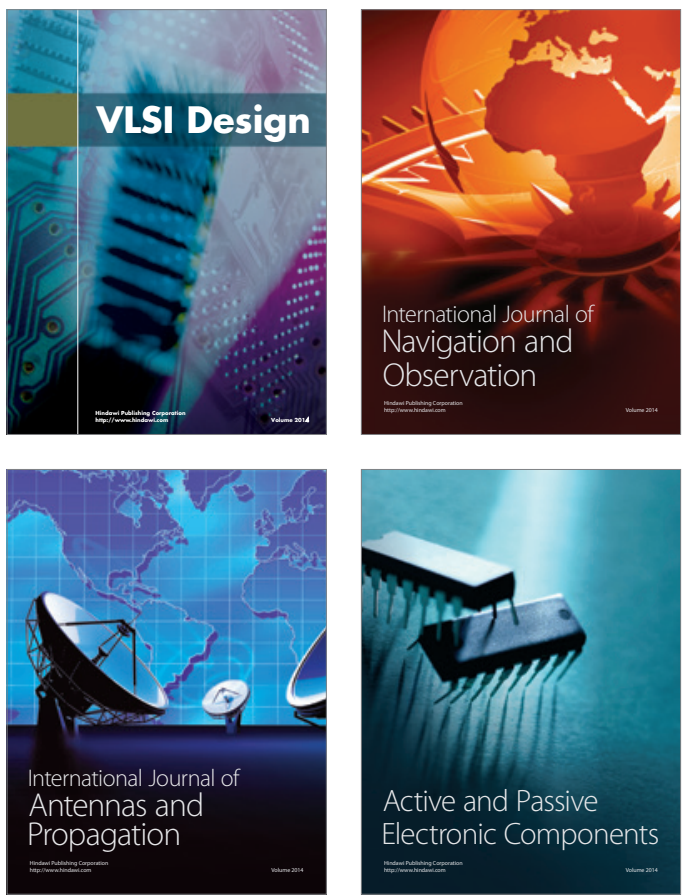
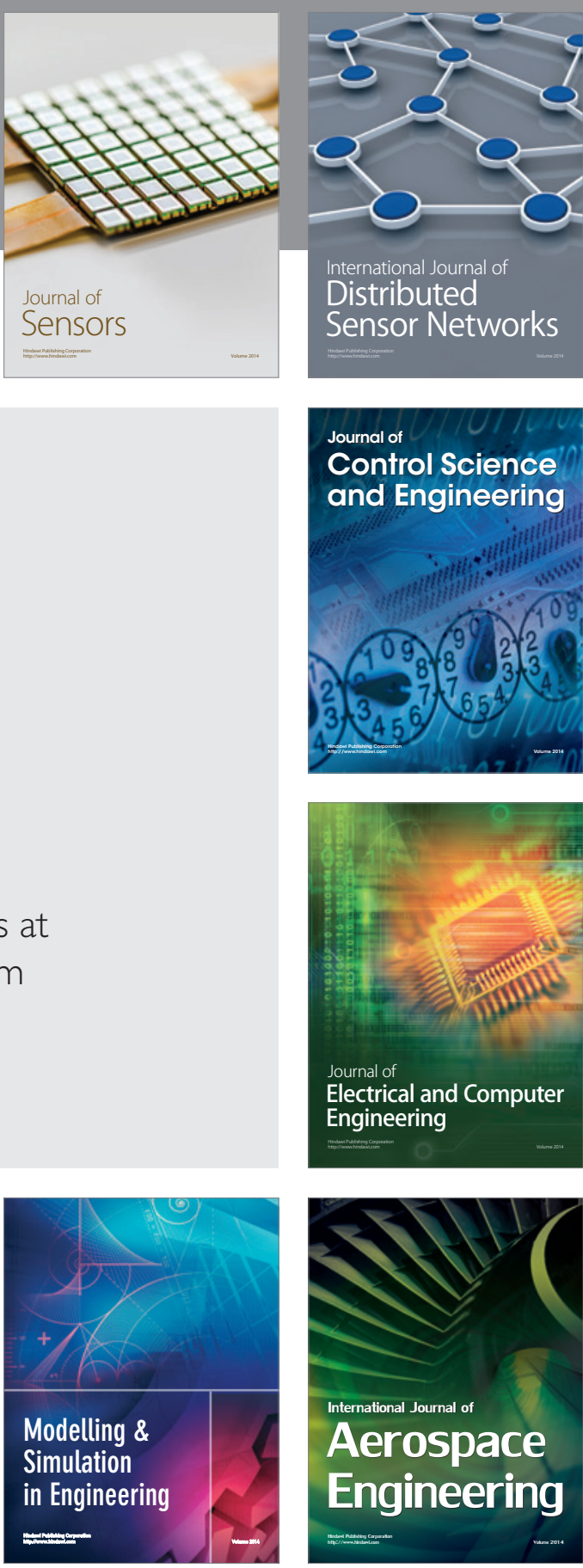

International Journal of

Distributed

Sensor Networks

Journal of

Control Science

and Engineering
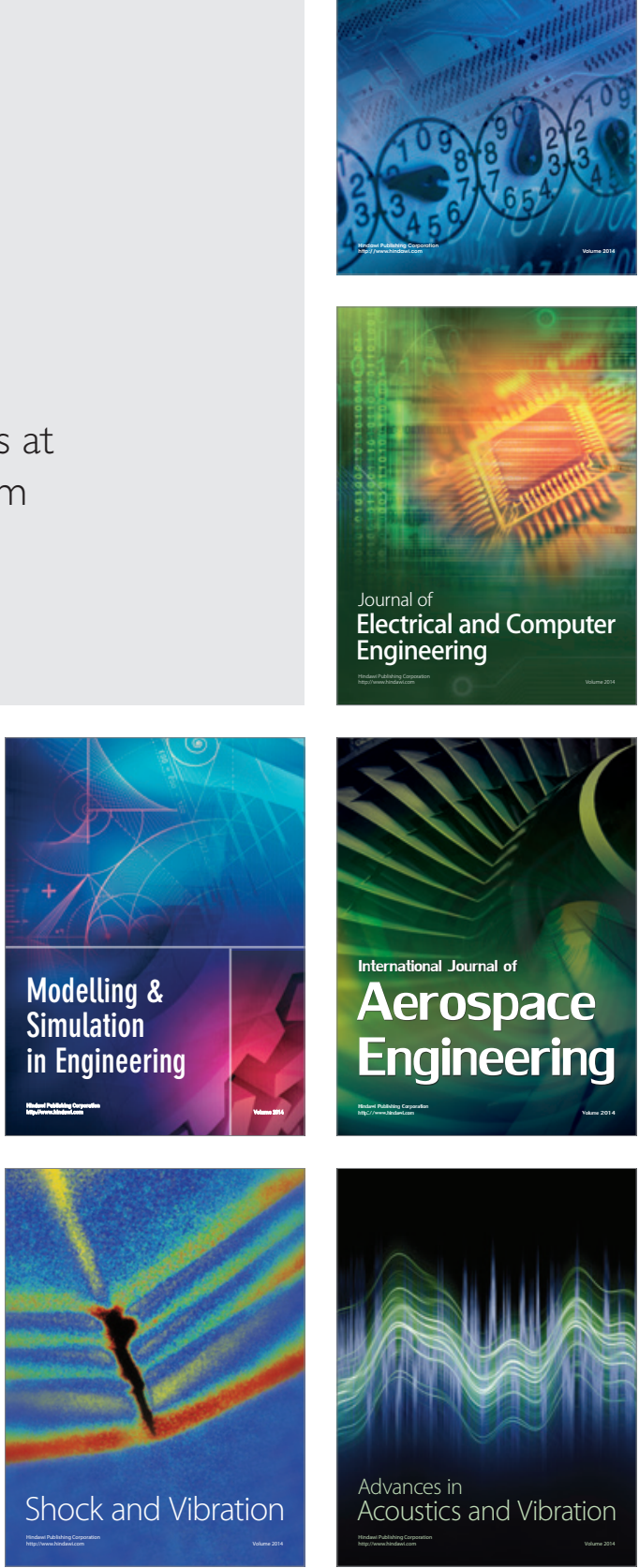